DOI: $10.33067 /$ SE.3.2020.1

\author{
Marianna Gladysh * \\ Viktor Sychov $\star \star$
}

\title{
The Influence of the Migration Crisis of 2015 on the EU Migration Policy
}

\begin{abstract}
Nowadays the European Union migration policy towards is one of the most important aspects in ensuring internal security of the EU. At the end of the XXth - beginning of the XXI century, Europe faced a new phenomenon - the intensification of migration processes, namely the influx of refugees and migrants-asylum seekers from third countries. Therefore, it led to the creation and development of common migration policy of the European Union. In this regard, it was important to create legislation that could regulate such issues as border security and combating illegal migration, as well as to create a common asylum system. The need to study the legal framework on which the EU policy on migrants and refugees is based, and to study the current state and trends in the migration policy of the member-states of the EU has determined the relevance of this study. The importance of this topic is intensified by the European migration crisis of 2015, which is even described as a humanitarian catastrophe caused by a massive influx of refugees from Africa and the Middle East. It showed the main problems in the sphere of migration policy and policy towards refugees: imperfection of the system of delimitation of the EU competencies; a large number of countries with conflicting interests in various spheres; fragmentation of programs in force at the national level. To address the migration crisis, the EU used a multifaceted strategy: improving
\end{abstract}

* Marianna Gladysh - Ivan Franko National University of Lviv, e-mail: mgladysh@ukr.net, ORCID: 0000-0003-4236-7110.

$\star \star$ Viktor Sychov - Ivan Franko National University of Lviv, e-mail: mr.victorsychov@gmail.com, ORCID: 0000-0002-7609-5267. 
and creating new migration management institutions, expanding crossregional dialogue with the countries of the Mediterranean region, Africa and the Middle East; continued to reformat the Mediterranean region (region-building). Potential approaches range from an internal search for strategies in which each member state seeks to defend its own interests (sometimes even against European integration processes) to a more farsighted approach in which member states work together to address a wide range of migration issues.

Keywords: European Union, Common Migration Policy, Migration Crisis

\section{Introduction}

The European Union itself and its Member states has become the main centre of gravity for migration in the world. The EU policy on migrants and refugees has a clear legal basis, formally enshrined in European law, designed to address political, economic, legal and security issues. The formation of the EU migration policy was based on one of the key principles of European integration - freedom of movement, as well as in accordance with certain international instruments. Among them the Universal Declaration of Human Rights signed in 1948 by the UN General Assembly and the 1951 Geneva Convention relating to the Status of Refugees, which is the main international legal act defining the status and rights of refugees.

The development of the EEC / EU migration policy could be divided into 5 periods: the first one $-1960-80$-ies; the second - the 1990s; the third - 1999-2009; fourth - 2009-2016; fifth - from 2015 till present.

The European migration crisis arose in the autumn of 2015 due to the diverse increase in the flow of refugees and illegal migrants to the European Union from the countries of North Africa, the Middle East and South Asia and the EU's not readiness to receive and distribute them. This migration crisis has become the largest in Europe since World War II.

\section{Stages of Formation of the EU Common Migration Policy}

Migration policy of the EU has only gradually and with great difficulties become the subject of joint efforts within the European Union. Migration problems have come to the agenda in European countries as one of the most pressing issues of socio-economic, cultural and political development. As the processes of globalization and integration deepened and expanded, Europe and the whole world faced a new problem - the 
advanced increase in immigration flows to countries that have not faced before the issue of acceptance, placement and adaptation of a significant number of immigrants. This primarily affected the countries of Western Europe, and in the last decade also the countries of Eastern Europe. The countries receiving immigrants face a whole range of tasks and problems related to the economic provisions for new migrants, their integration into new social and political conditions, problems of tolerance (primarily, national and religious), adherence to human rights and ensuring national security are of particular importance. At the beginning of the XXI century, the European Union faced several global challenges.

Migration issues and development of common migration policy of the EU has gone through several stages and every stage has its peculiarities and difficulties.

The main feature of the 1945-1960s was a very rapid post-war process of recovery and further development of the economies of Western European countries, which required the involvement of a large number of workers from abroad. This was carried out mainly through interstate agreements on a contract basis. A large number of workers were attracted from warweakened and less developed European countries (Spain, Portugal, Italy, Greece) to more developed countries (France, Great Britain, Germany, Denmark, Switzerland and the Nordic countries). This policy was a consequence of the post-war labour shortage in these countries.

The host countries' policies on recruited workers were restrictive until the early 1960s. Labour migrants were provided with short-term visas (for 1 year with subsequent renewal), they did not have the opportunity to obtain visas for the residence of their families. Also, workers from former colonies that retained traditional economic and cultural ties with the metropolises were received, for example, North Africa (Maghreb countries) was a supplier of labour force to France.

During the period at the end of 1960s - the beginning of the 1970s the economic situation in southern European countries improved significantly and they gradually began to turn into host countries. Under the pressure from the governments of these countries, the visa regime in the European space was simplified. In particular, long-term five-year visas were introduced and, most importantly, it became possible for the family members of labour migrants to stay in the receiving countries. This period was also characterized by a large influx of repatriates to the countries of origin. About 6.5 million people moved from the former colonies to the metropolis, including 4.6 million metropolitan citizens and 1.9 million indigenous inhabitants of the colonies. More than 1 million ethnic Germans by the mid-1960s returned home. In addition, significant flows 
of refugees and persons traveling for family reunification moved from Eastern and Central Europe to Western Europe. ${ }^{1}$

The next stage in the development of migration and migration policy in Western Europe began in 1973 (the beginning of the oil crisis) and continued until the end of the 1990s. It was a period of all kinds of containment of immigration flows, gradual reorientation of the migration vectors from the South-North to the East-West. This stage was also characterized by the predominance of labour flows within Western European countries, as well as from the former colonies.

After the 1973 oil crisis, the governments of the European countries drastically reduced their labour migrants from neighbouring countries, and even more - from distant countries, who tried to return to their homeland by stopping the issuance of work visas. However, only a small part of the migrants returned home, the rest already took their families to Western Europe. The mechanism of stepwise migration had already been launched; channels of communication were formed through relatives and acquaintances, and by the mid-1980s in many countries, a percentage of migrants constituted a significant part of the labour force (including illegal).

Late 1980s - early 1990s was the period of the beginning of the unification of the countries of Western Europe. The signing of the Maastricht Treaty in 1992 had a positive effect for migrants, legalizing them in their countries of residence. It stated that any citizen of a Member State is a citizen of the Union, that, among other things, enjoys the right to move freely and choose a place of residence throughout its territory. Asylum policy, rules for crossing and controlling external borders, immigration policy (conditions of entry, movement, residence, family reunification, employment of foreigners, prevention of unauthorized immigration) were qualified by the Maastricht Treaty as being of common interest and should be decided on an intergovernmental basis.

Migration issues still remained within the competence of the Member States. Moreover, the Maastricht Treaty stated that nothing could prevent the governments from taking the measures they deemed necessary to control immigration from third countries, prevent crime and smuggling. ${ }^{2}$

The main EU institutions still had very little power in this area. Decisions were taken mostly in the form of recommendations and only

1 S. Castles, M.J. Miller, The Age of Migration. International Population Movements in the Modern World, Macmillan Press, London 1998.

2 Population and Migration in the European Union, ed. P. Rees et al., Chichester 1996, p. 313. 
with complete consensus. However, after signing of the Maastricht Treaty, the EU members were able to agree on many important issues, which were later incorporated into common law.

A significant step in the formation of a common European migration area was the entry into force in 1995 of the Schengen Agreement, ${ }^{3}$ which was signed on 14 June 1985 by seven European countries (Benelux countries, France, Germany, Portugal and Spain) and ratified on 26 March 1995. In 1996, Norway and Iceland, which are not members of the EU, concluded special agreements on their participation in the arrangements. In 1997, Italy, Austria and Greece joined the Schengen Agreements. Most Central European countries acquired the EU membership in 2004 and joined the Schengen area in 2007. In 2009, Switzerland, which is not a member of the European Union, also joined the agreement.

The Schengen Agreement aimed to abolish border controls among the Member States. In order to prevent the undesirable consequences of the abolition of border controls, the Convention on the application of the Schengen Agreement (1990) provided for measures to combat uncontrolled migration, trade of guns and drugs, and smuggling. It introduced a constant exchange of information and cooperation between law enforcement and judicial institutions of different countries, in particular, the creation of the Schengen Information System, where data on all persons who, under certain circumstances, attracted the attention of the law enforcement agencies of the participating countries were to be entered.

The Schengen agreements also provided for the harmonization of visa policy. A single-entry visa, common criteria for issuing visas and a list of countries which citizens must have visas to enter the Schengen area were introduced.

Signing of the Treaty of Amsterdam in $1997^{4}$ (entered into force in 1999) became a turning point in the harmonization of European migration policy, with a separate section on freedom of movement, asylum and immigration.

The Amsterdam Treaty contained a provision that allowed the EU to adopt binding migration laws for member states. In October 1999,

3 The Schengen acquis - Agreement between the Governments of the States of the Benelux Economic Union, the Federal Republic of Germany and the French Republic on the gradual abolition of checks at their common borders. Official Journal L 239, 22/09/2000, P. 0013-0018.

4 Treaty of Amsterdam amending the Treaty on European Union, the Treaties establishing the European Communities and certain related acts. Official Journal C 340, 10/11/1997, P. 0001-0144, https://eur-lex.europa.eu/legal-content/EN/ TXT/?uri $=$ CELEX:11997D/TXT (access 3.05.2020). 
at the summit in Tampere, the heads of the EU Member States agreed to implement the Amsterdam Agreement, in particular in the field of immigration and asylum. A special program was approved, outlining the ultimate and short-term, for five years, goals of creating a common system for regulating migration in the EU.

The Treaty of Nice in 2003 started a new stage in the formation of the EU legislation in the field of migration policy. The most important documents at the beginning of this stage were The Dublin II Regulation ${ }^{5}$ which was adopted in 2003 replaced the Dublin Convention in all EU Member States except Denmark, and the 2005 Hague Program ${ }^{6}$ which not only drew attention to the need for cooperation in the field of protection of migrants under the 1951 Geneva Convention, but also focused on settling migration flows and the fight against cross-border crime. The Program included the creation of a common European asylum system, which had to include a single asylum procedure and a single status for asylum seekers. The main aim of this Program was the integration of third-country nationals into European community.

In 2008, the European Commission analyzed the migration situation in Europe at the beginning of the XXI century and summed up the results of the first stage of EU migration policy formation. ${ }^{7}$ The principles of migration policy, which were at the same time the main activities in the sphere of migration were formulated, the necessary measures and tools for their implementation were outlined. The first principle was to create a clear and transparent system of rules and procedures to ensure legal migration. It included the necessity to provide third-country nationals with the necessary information on legal entry and stay in the EU, guarantee of their rights, which should be close to those that the EU citizens enjoyed, a flexible common visa policy, especially for temporary visits and travel of educational and professional purposes.

According to the second principle, economic migration should meet the needs of the EU labour market, not only in quantity but also in quality,

5 The Dublin II Regulation. Council Regulation (EC) No 343/2003 of 18 February 2003 establishing the criteria and mechanisms for determining the Member State responsible for examining an asylum application lodged in one of the Member States by a third-country national, https://eur-lex.europa.eu/legal-content/EN/TXT/HTM L/?uri=LEGISSUM:133153\&from $=\mathrm{EN}$ (access 15.05.2020).

6 The Hague Programme: strengthening freedom, security and justice in the European Union (2005/C 53/01). 3.3.2005, pp. 1-14, https://eur-lex.europa.eu/legalcontent/EN/ALL/?uri=CELEX\%3A52005XG0303\%2801\%29 (access 18.05.2020).

7 A Common Immigration Policy for Europe: Principles, actions and tools (COM(2008) 359 final), http://eur-lex.europa.eu/LexUriServ/LexUriServ.do?uri= COM:2008:0359:FIN:EN:PDF (access 3.06.2020). 
i.e. in terms of professional qualifications, which would promote economic growth. The implementation of this principle should not contradict the rights of migrants as well as the preferences enjoyed by EU citizens in the labour market, it also should ensure the right of each Member State to determine economic migration to its territory, in close cooperation with social partners, employers and local authorities. To meet the needs of the EU labour market, it was proposed to organize vocational training for potential migrants, including in the countries of origin, to recognize the qualifications acquired at the countries of origin, to promote the employment of migrants, especially women, as well as the development of entrepreneurial activity of migrants.

The adoption of the Lisbon Treaty in $2009^{8}$ made significant changes in the EU institutional and functional levels. The entry into force of this document marked the beginning of a new level of integration within the EU, its new role in external relations, and a new level of harmonization and unification of migration policy. Article 79 of Lisbon Treaty states the need for a common migration policy, and contains a detailed list of issues that need to be regulated at the EU level.

At the same time, communitarianization applied not only to those areas where the European Union was so strong enough - the struggle with illegal migration and international migration readmission agreements. The common migration policy also included the management of legal migration, including the integration of immigrants. The principle of solidarity of the EU Member States in the division of responsibilities for border protection and regulation of the influx of refugees was applied.

In 2009 the Stockholm Program ${ }^{9}$ was adopted, though it happened in the midst of the financial and economic crisis and demonstrated the reluctance of EU Member States to step up cooperation on migration issues. In general, the EU's efforts in the sphere of common migration policy during the crisis focused on maintaining the results already achieved and ensuring the functioning of the existing agreements, in particular the Schengen system. It should be noted that such five-year programs like the Stockholm Program are purely political documents, which means that they are not a part of the EU law and are therefore they

${ }^{8}$ Treaty of Lisbon amending the Treaty on European Union and the Treaty establishing the European Community (2007/C 306/01), 17.12.2007, https://eur-lex.europa. eu/legal-content/EN/TXT/?uri=celex\%3A12007L\%2FTXT (access 12.06.2020).

9 The Stockholm Programme - An open and secure Europe serving and protecting the citizens. (2010/C 115/01), 4.5.2010, https://eur-lex.europa.eu/LexUriServ/LexUriServ.do?uri=OJ:C:2010:115:0001:0038:EN:PDF (access 12.06.2020). 
are not binding. At the same time, they outline the main directions of the common migration policy and the means to achieve certain goals.

In order to simplify bureaucratic procedures in the immigration process, in 2011 a Directive 2011/98 was adopted to introduce a single permit for both employment and residence of third-country nationals in the EU, as well as a common list of rights and freedoms they can enjoy. This decision was aimed at improving the situation with migrants and their ability to adapt in the host countries. ${ }^{10}$

The approval of "Global Approach to Migration and Mobility"11 in 2011 became an important step in the development of the EU migration policy. It defined how the EU conducts its policy dialogues and cooperation with non-EU countries, based on clearly defined priorities and embedded in the EU's overall external action, including development cooperation.

In April 2012, the European Council approved "EU Action on Migratory Pressures - A Strategic Response"12 which included a number of strategic priorities of the European Union in the migration sphere. They were as follows: strengthening cooperation with countries of origin and transit on migration management; improving the management of external borders; prevention of illegal migration across the Turkish-Greek border; ensuring compliance with the right to freedom of movement while preventing its abuse by third-country nationals; improving the system of regulation of migration movements, including the return of migrants home.

Despite all the efforts of the leadership of the EU and its Member States and the adoption of the above-mentioned documents, illegal migration seriously affects both the EU in general and Member States' security. In the sphere of migration the European countries still have unsolved problems: 1) an unprecedented increase in the scale of immigration, including illegal. This is due to the fact that for a long time

${ }_{10}$ Directive 2011/98/EU of the European Parliament and of the Council of 13 December 2011 on a single application procedure for a single permit for thirdcountry nationals to reside and work in the territory of a Member State and on a common set of rights for third-country workers legally residing in a Member State, http://eurlex.europa.eu/LexUriServ/LexUriServ.do?uri=OJ:L:2011:343:0001:0009:EN:PDF (access 18.05.2020).

${ }^{11}$ Communication from the Commission to the European Parliament, the Council, the European Economic and Social Committee and the Committee of the Regions The Global Approach to Migration and Mobility / $\star$ COM/2011/0743 final/. 52011DC0743. Brussels, 18.11.2011, COM(2011) 743 final, https://eur-lex.europa. $\mathrm{eu} /$ legal-content/EN/TXT/PDF/?uri $=\mathrm{CELEX}: 52011 \mathrm{DC} 0743 \&$ from $=\mathrm{EN}$ (access 22.05.2020).

12 EU Action on Migratory Pressures - A Strategic Response, https://www.eumonitor.eu/9353000/1/j9vvik7mlc3gyxp/vj6ipob6bkr4 (access 17.06.2020). 
the leadership of European countries neglected the influx of illegal labour migrants, as a result of which illegal immigration in recent decades has become an integral feature of the development of many countries; 2) the transformation of some European countries from suppliers of migrants to other European countries into direct centres of immigrants today. In particular, Italy, Spain, Portugal and Greece, which were previously the main sources of immigrants in Europe, are now the so-called new European centres of immigration; 3 ) the emergence of isolated immigrant ethnic communities which is a potential basis for the existence of hidden conflicts that may escalate into intercultural confrontation; 4) the growth of organized crime because of the poor integration of the migrants in to the society; 5) the existence in the EU of a problem of "vicious circle", which consists, on the one hand, in counteracting immigration flows, and on the other - in compliance with the principles declared by international law: protection of migrants' rights, fight against poverty, etc. Under European law, the key issue is to strengthen the protection of human rights, which makes it difficult for governments to expel migrants or deprive them of the right to live with their families.

We must admit that the very structure of the central bodies of the European Union is bureaucratic and tightly regulated. In pursuit of a sound and balanced policy on internal and external migration, the European Commission and the governments of the Member States have sought to find such a form of reconciling common and individual interests, which would best serve the interests of community development.

\section{Countering the Migration Crisis in 2015 and Areas for Improvement of the EU Migration Policy}

In 2015 the EU experienced a significant migration crisis caused by military conflicts and poverty in Syria, Iraq, Afghanistan, Africa, South Asia and other countries and regions. More than 1 million refugees and migrants reached Europe by sea in 2015 and about 362 thousand in 2016. Many migrants later tried to travel further north to Germany and Sweden, where they believed they could get asylum and better social assistance.

During 2015, various EU crisis management initiatives were generally not very successful. The EU was criticized for the lack of a coherent and effective migration policy, which is difficult to shape due to Member States' national sovereignty issues and their sensitivity to minority issues, integration and identity. Migration flows have also created deep differences within the EU. Greece and Italy, as well as other major destination countries, expressed concern about the lack of European solidarity, 
while others argued that traditionally generous asylum policies in such countries like Germany and Sweden have become "attraction" factors and have only increased migration flows. Some governments of the EU member states hoped for Germany's statement in August 2015 that the EU's "Dublin Conditions" would no longer be applied (according to which the first country to apply for asylum is responsible for its consideration), which provided for a unilateral procedure for the EU asylum procedure and did not allow for consideration of the consequences for the whole EU.

The efforts to set up redistribution and resettlement programs at EU level, which would assume that a member state would accept a significant number of asylum seekers and refugees (in particular to alleviate the burden on Greece and Italy), have been quite controversial. The biggest opponents of the new programs were the countries of Central and Eastern Europe, fearing that newly arrived migrants and refugees, many of whom were Muslims, could change the Christian identities of these countries and Europe in general.

Although the EU approved a limited but mandatory plan to relocate asylum seekers from Greece and Italy in September 2015, the result was achieved by using a qualified EU majority voting system rather than consensus (Hungary, Czech Republic, Slovakia and Romania voted against the plan, while Finland abstained).

The adoption of a proposal on such a sensitive issue, directly related to the sovereignty and territorial integrity of the states, has become unprecedented in the EU, and therefore many observers considered it necessary to conduct a second voting, which was seen as a manifestation of deep divisions within the Union.

Because the number of refugees and migrants who came to Europe decreased in early 2016, the EU began to focus on trying to stop migration. In March 2016, the EU leaders agreed to end the "wave" through an approach that allowed individuals from Greece to travel to the Western Balkans and then seek asylum in other EU countries. In addition, a thematic agreement was reached with Turkey. In fact, since then, the fifth modern stage in the development of EU migration policy has begun, related to the increasing importance of the "external dimension" of the EU in the implementation of its migration policy in general and in migration crisis management, in particular.

The main provisions of the EU's agreement with Turkey focus on the return of all new "illegal migrants" crossing the Turkish border on their way to Greece in exchange for the resettlement of one Syrian refugee from Turkey for each returned Syrian migrant. 
In addition, the EU has promised to speed up the disbursement of previously allocated 3 billion euros aid to Turkey and provide additional assistance to Syrian refugees in Turkey. As these measures came into force, the number of migrants and refugees reaching Europe decreased significantly. However, the EU's agreement with Turkey remains controversial and potentially unreliable.

The failed coup attempt in Turkey in July 2016 and the position of the current Turkish government have heightened tensions between the EU and Turkey. Although Turkey has made progress in meeting most of the EU's visa-free requirements, some issues remain unresolved.

In November 2016, the European Parliament adopted a recommendation resolution calling for the termination of negotiations on Turkey's accession to the EU until the Turkish government stops the "disproportionate" response to the failed coup in the country. In view of this, some observers believe that the EU agreement with Turkey on refugees and migration flows may not be executed. Although the agreement with Turkey helped to stop migration flows to Greece, Italy experienced a sharp increase in the flow of migrants and refugees from Africa, including Libya (mid-2016)

Refugee migration flows continue to have significant implications on the EU member states. First of all, migratory pressures have seriously shaken the Schengen system, which depends, to a large extent, on confidence in the security of the Union's external borders. In 2015, several Schengen countries (including Germany, Austria, Denmark and Sweden) introduced temporary border controls in response to migratory pressures. These temporary border management measures remain in place, and some experts fear they may become permanent.

The EU officials say they remain committed to the Schengen system and are working to strengthen EU border controls, including through the creation of a new European Border and Coast Guard to strengthen national capacity at the external borders (2016) through joint operations and rapid border measures.

The arrival of refugees and migrants raised the question of the ability of European countries to integrate refugees into European culture and society. Such fears have become more pronounced in the face of reports of criminal activity and attacks by individual migrants and asylum seekers, as well as recent terrorist acts in Europe by Muslim-born extremists born and / or raised in Europe. At the same time, there are well-founded fears of rising social tensions and xenophobia in Europe. Germany, Sweden and other EU countries note an increase in the number of cases of violence against migrants and refugees. 
Managing international migration is at the top of the EU's policy agenda, in part as a result of growing problems in a multicultural society in host countries. Instead of the former restrictive policy, there has been a trend towards selective policies, including experiments with cyclical migration. Nowadays, there are two opposing views on whether international migration leads to impoverishment or, conversely, to sustainable development.

The political crisis in Europe in 2015 due to excessive flows of migration and refugees revealed the lack of a coordinated approach of the European Union on these issues. Three aspects emphasize the lack of coordination among the EU member states: 1) the system of shared competencies of the EU; 2) member states with conflicting interests in different areas; 3) fragmentation of existing programs at the national level. In order to overcome these aspects, it is necessary to achieve a common understanding of the importance of joint actions at the EU level.

To resolve the migration crisis the EU used a multifaceted strategy: improvingand creating new migration managementinstitutions, expanding cross-regional dialogue with the countries of the Mediterranean region, Africa and the Middle East; continued to reformat the Mediterranean region (region-building). The EU's acquired experience can be of practical interest to the states and regions, which have yet to face similar challenges.

\section{Conclusions}

The dynamic changes that have covered almost all spheres of the modern world necessitate the deepening of cooperation among the states in order to effectively meet social needs. One of the areas of such cooperation is cooperation on migration issues. Migration is a complex phenomenon accompanied by multifaceted and heterogeneous social processes that not only affect social development, but also is affected by political, socio-economic, demographic transformations.

Nowadays, along with the free movement of goods, capital and services, the free movement of persons is an important component of the integration processes covered by common EU policies. The signing of the first Schengen Agreement (1985) was an important step in establishing a single space for the free movement of persons and the movement of goods and services within the Community. The Schengen area can be characterized by two features: on one hand, it is the "transparency" of internal borders, on the other hand- the implementation of a single visa regime at external borders. 
Member States declared their readiness to coordinate migration policy at the 1999 European Council in Tampere. A milestone in the formation of a common EU migration policy was the adoption of the Hague Program (2004), which contained ambitious plans to achieve joint policy decisions in the field of migration and asylum by 2010. In contrast to the program approved in Tampere, the Hague Program included provisions on legal immigration to the EU, it is also emphasized on foreign policy dimension of migration policy.

The Lisbon Treaty (2007) made significant changes to the order of formation of the EU migration policy. According to it, migration policy of the EU underwent significant changes: migration issues were completely transferred to the competence of the community, the rights and opportunities of the European Parliament, the European Commission and the European Court of Justice, the decision-making process in Parliament has been simplified, and the EU Council has been given the power to identify the main directions for the development of legislation and operational planning in the area of freedom, security and justice including migration issues.

In 2015 the EU experienced a significant migration crisis caused by military conflicts and poverty in Syria, Iraq, Afghanistan, Africa, South Asia, and other countries and regions. Various EU initiatives with crisis management in general were very successful. The EU was criticized for the inconsistency and ineffectiveness of migration policies due to member states' national sovereignty issues and their sensitivity to minority issues, integration and identity.

Coordination of the efforts by the EU member states hinders: 1) imperfection of the system of delimitation of the EU competencies; 2) a large number of countries with conflicting interests in various spheres; 3) fragmentation of programs in force at the national level. To address the migration crisis, the EU used a multifaceted strategy: improving and creating new migration management institutions, expanding crossregional dialogue with the countries of the Mediterranean region, Africa and the Middle East; continued to reformat the Mediterranean region (region-building).

Potential approaches range from an internal search for strategies in which each member state seeks to defend its own interests (sometimes even against European integration processes) to a more far-sighted approach in which member states work together to address a wide range of migration issues. 


\section{References}

A Common Immigration Policy for Europe: Principles, actions and tools (COM(2008) 359 final), http://eur-lex.europa.eu/LexUriServ/ LexUriServ.do?uri=COM:2008:0359:FIN:EN:PDF (access 3.06.2020).

Castles S., Miller M.J., The Age of Migration. International Population Movements in the Modern World, Macmillan Press, London 1998.

Communication from the Commission to the European Parliament, the Council, the European Economic and Social Committee and the Committee of the Regions The Global Approach to Migration and Mobility (COM/2011/0743 final. 52011DC0743. Brussels, 18.11.2011, COM(2011)743final,https://eur-lex.europa.eu/legal-content/EN/TXT/ $\mathrm{PDF} /$ ?uri=CELEX:52011DC0743\&from $=\mathrm{EN}$ (access 22.05.2020).

Directive 2011/98/EU of the European Parliament and of the Council of 13 December 2011 on a single application procedure for a single permit for thirdcountry nationals to reside and work in the territory of a Member State and on a common set of rights for third-country workers legally residing in a Member State, http://eur-lex.europa.eu/ LexUriServ/LexUriServ.do?uri=OJ:L:2011:343:0001:0009:EN:PDF (access 18.05.2020).

EU Action on Migratory Pressures - A Strategic Response, https:// www.eumonitor.eu/9353000/1/j9vvik7m1c3gyxp/vj6ipob6bkr4 (access 17.06.2020).

Population and Migration in the European Union, ed. P. Rees et al., Chichester 1996.

The Dublin II Regulation. Council Regulation (EC) No 343/2003 of 18 February 2003 establishing the criteria and mechanisms for determining the Member State responsible for examining an asylum application lodged in one of the Member States by a third-country national, https://eur-lex.europa.eu/legal-content/EN/TXT/HTML/?ur $\mathrm{i}=$ LEGISSUM:133153\&from $=\mathrm{EN}$ (access 15.05.2020).

The Hague Programme: strengthening freedom, security and justice in the European Union. (2005/C 53/01), 3.3.2005, https://eur-lex.europa. $\mathrm{eu} /$ legal-content/EN/ALL/?uri=CELEX\%3A52005XG0303\%2801\%2 9 (access 18.05.2020).

The Schengen acquis - Agreement between the Governments of the States of the Benelux Economic Union, the Federal Republic of Germany and the French Republic on the gradual abolition of checks at their common borders. Official Journal L 239, 22/09/2000.

The Stockholm Programme - An open and secure Europe serving and protecting the citizens (2010/C 115/01), 4.5.2010, https://eur-lex.europa. 
eu/LexUriServ/LexUriServ.do?uri=OJ:C:2010:115:0001:0038: EN:PDF (access 12.06.2020).

Treaty of Amsterdam amending the Treaty on European Union, the Treaties establishing the European Communities and certain related acts. Official Journal C 340, 10/11/1997, https://eur-lex.europa.eu/legalcontent/EN/TXT/?uri=CELEX:11997D/TXT (access 3.05.2020).

Treaty of Lisbon amending the Treaty on European Union and the Treaty establishing the European Community (2007/C 306/01), 17.12.2007, https://eur-lex.europa.eu/legal-content/EN/TXT/?uri=celex\%3A 12007L\%2FTXT (access 12.06.2020). 